\title{
Cytological Evidence of an Active Role of Silicon in Wheat Resistance to Powdery Mildew (Blumeria graminis f. sp. tritici)
}

\author{
R. R. Bélanger, Nicole Benhamou, and J. G. Menzies
}

First and second authors: Département de phytologie-FSAA, Université Laval, Québec, Qc, G1K 7P4; and third author: Agriculture and Agri-Food Canada, 195 Dafoe Road, Winnipeg, MB, R3T 2M9.

Accepted for publication 25 September 2002.

\begin{abstract}
Bélanger, R. R., Benhamou, N., and Menzies, J. G. 2003. Cytological evidence of an active role of silicon in wheat resistance to powdery mildew (Blumeria graminis f. sp. tritici). Phytopathology 93:402-412.

Silicon (Si) amendments in the form of exogenously supplied nutrient solution or calcium silicate slag protect wheat plants from powdery mildew disease caused by the fungus Blumeria graminis f. sp. tritici. The most striking difference between $\mathrm{Si}-$ and $\mathrm{Si}+$ plants challenged with $B$. graminis f. sp. tritici was the extent of epidermal cell infection and colonization by $B$. graminis f. sp. tritici. Histological and ultrastructural

analyses revealed that epidermal cells of $\mathrm{Si}+$ plants reacted to $B$. graminis f. sp. tritici attack with specific defense reactions including papilla formation, production of callose, and release of electron-dense osmiophilic material identified by cytochemical labeling as glycosilated phenolics. Phenolic material not only accumulated along the cell wall but also was associated with altered integrity of haustoria in a manner similar to localized phytoalexins as reported from other pathosystems. These results strongly suggest that $\mathrm{Si}$ mediates active localized cell defenses against $B$. graminis f. sp. tritici attack.
\end{abstract}

It has long been known that silicon ( $\mathrm{Si}$ ) plays an important role in the resistance of plants against pathogens $(19,39)$. The mechanisms by which $\mathrm{Si}$ mediates disease resistance is incompletely understood. Historically, it was assumed that insoluble $\mathrm{Si}$, accumulating in the apoplast, creates a mechanical barrier preventing fungal penetration (23). This suggestion was thought to apply to many pathosystems including rice-rice blast, oat-powdery mildew, barley-powdery mildew, and cucumber-powdery mildew, etc. $(7,33,40,42)$. Kunoh and Ishizaki (26) demonstrated localized accumulation of insoluble $\mathrm{Si}$ at penetration sites of powdery mildew pathogens. However, neither they nor Carver et al. (7) could directly relate the presence of insoluble $\mathrm{Si}$ to resistance to penetration. In a similar approach with the Pythium-cucumber pathosystem, Chérif et al. (10) demonstrated that although $\mathrm{Si}$ failed to accumulate at penetration points under conditions of saturated humidity, resistance was still enhanced. They concluded that, in cucumber, Pythium resistance did not result from insoluble Si accumulating within plant tissues and cell walls; rather, they (9) hypothesized that soluble Si played a physiological role resulting in upregulation of plant defenses.

Pursuant to the concept that $\mathrm{Si}$ mediates active defense mechanisms, Chérif et al. (8) showed that in the cucumber-Pythium interaction, supplying Si enhanced the activities of chitinases, peroxidases, polyphenoloxidases, and phenolics. Fawe et al. (15), using the cucumber-powdery mildew pathosystem demonstrated the production of specific phytoalexins associated with Si-mediated resistance. By comparing the properties of known responses occurring as a result of systemic acquired resistance with those occurring in the presence of soluble Si in planta, Fawe et al. (16) suggested that $\mathrm{Si}$-mediated resistance shares functional similarities with forms of induced resistance.

Corresponding author: R. R. Bélanger

E-mail address: richard.belanger@plg.ulaval.ca

Publication no. P-2003-0121-01R

(C) 2003 The American Phytopathological Society
In monocots, little emphasis has been placed on the possibility that Si plays a role in activating host defenses. Most researchers have simply correlated the presence of insoluble Si with increased resistance to fungal penetration (43). Although the hypothesis of a simple physical barrier has become widely accepted, alternatives for other functions of Si have evolved. For instance, Deren (12) reported a negative correlation between $\mathrm{Si}$ concentration in leaf tissues and plant disease development in different rice cultivars. In addition, Carver et al. (7) trying to correlate Si accumulation with fungal penetration, concluded that insoluble $\mathrm{Si}$ was not the only factor influencing the outcome of attempted penetration. This prompted Zeyen et al. (41) to speculate that high levels of soluble $\mathrm{Si}$ in cells at the time of attempted powdery mildew penetration may have a physiological or biochemical role in mediating cellular resistance.

In light of the uncertainty regarding the roles of Si in planta, we examined the cytological effects of $\mathrm{Si}$ amendments in the wheat (Triticum aestivum L.) and powdery mildew (Blumeria graminis DC f. sp. tritici Ém. Marchal) pathosystem. The objectives were (i) to confirm that $\mathrm{Si}$ amendments can influence $B$. graminis f. sp. tritici incidence and development in wheat; and (ii) to characterize and localize key cellular constituents occurring in Si treated ( $\mathrm{Si}+$ ) and $\mathrm{Si}$ untreated $(\mathrm{Si}-)$ wheat epidermal cells challenged by $B$. graminis f. sp. tritici.

\section{MATERIALS AND METHODS}

Plant material and silicon amendment. Seeds of wheat (cv. HY 644), donated by A. Comeau (Agriculture and Agri-Food Canada, Sainte-Foy Research Station), were sown in Pro-Mix (Tourbières Premier, Rivière-du-Loup, Quebec) in 10-cm pots (10 seeds per pot) and watered daily. Other seeds were sown in ProMix to which Reclime (calcium silicate slag) (RECMIX Inc., Sorel, Quebec) was added at a rate of $3 \mathrm{~g}$ per pot or an equivalent of approximately 3 tonnes ha ${ }^{-1}$. After 14 days, plants were transferred to a greenhouse compartment maintained at $21 / 18^{\circ} \mathrm{C}$ with a relative humidity of $70 \%$ and a photoperiod of $12 \mathrm{~h}$ with a photosynthetic photon flux of $\approx 1,000 \mu \mathrm{mol} \mathrm{m} \mathrm{m}^{-2} \mathrm{~s}^{-1}$. Plants were fertil- 
ized every other day with a standard Hoagland solution amended (Si+) or not amended (Si-) with $1.5 \mathrm{mM} \mathrm{SiO}_{2}$ (Kasil 6, National Silicates, Toronto). Plants treated with Reclime were fertilized with a standard Hoagland solution only. For each treatment ( $\mathrm{Si}-$, $\mathrm{Si}+$ and Reclime), a total of 120 plants (12 pots) were grown for 7 days before being inoculated. For controls, two pots per treatment were isolated in a separate greenhouse compartment and not subjected to inoculation.

Inoculation with $B$. graminis f. sp. tritici and disease assessment. One day before inoculation, wheat plants maintained in a growth cabinet and heavily infested with $B$. graminis f. sp. tritici were shaken to displace older spores ensuring that freshly formed conidia were available. The following day, 10 leaf segments bearing conidia were harvested, and for each pot, one segment was used to inoculate the experimental plants by gently brushing the segment over them. Inoculated plants were then observed daily for powdery mildew development. At the first visible sign of the fungal colonies, plants were scored for fungal presence on a scale of 0 to 4 , where $0=$ no colonization; $1=1$ to $5 \%$ of leaf area covered; $2=6$ to $20 \% ; 3=21$ to $40 \%$; and $4=41 \%+$. All 10 plants from each pot represented one experimental unit. Assessments were made every week for 5 weeks. Data were subjected to analysis of variance (ANOVA) using Super ANOVA version 1.11 (Abacus Concepts Inc., Berkeley, CA).

Tissue processing for light and transmission electron microscopy. Samples $\left(20 \mathrm{~mm}^{2}\right)$ were excised from control and inoculated leaves ( $\mathrm{Si}-$ and $\mathrm{Si}+$ plants) from sites where the fungus grew and pre-embedded in $2 \%$ aqueous Bacto-agar in order to hold fungal structures in place. They were then immersed in $3 \%(\mathrm{vol} / \mathrm{vol})$ glutaraldehyde in $0.1 \mathrm{M}$ sodium cacodylate buffer, $\mathrm{pH} 7.2$, for $2 \mathrm{~h}$ at room temperature and postfixed with $1 \%$ (wt/vol) osmium tetroxide in the same buffer for $1 \mathrm{~h}$ at $4^{\circ} \mathrm{C}$ prior to dehydration in a graded ethanol series and embedding in Epon 812. Thin sections $(0.7 \mu \mathrm{m})$, cut from the Epon-embedded material with glass knives, were mounted on glass slides and stained with $1 \%$ aqueous toluidine blue prior to examination with a microscope (Zeiss Axioscope; Carl Zeiss Canada, Don Mills, Ontario, Canada). Ultrathin sections $(0.1 \mu \mathrm{m})$, collected on nickel grids, were either stained with uranyl acetate and lead citrate for immediate examination with a transmission electron microscope (JEOL 1200 EX; JEOL, Tokyo) operating at $80 \mathrm{kV}$ or further processed for cytochemical labeling with probes for cellulose, chitin, callose, phenolics, and glycosylation. For each treatment, a minimum of five samples from three different leaves were investigated. For each sample, 10 to 15 ultrathin sections were examined under the electron microscope.

Preparation of the gold-complexed probes. Colloidal gold with particles averaging $12 \mathrm{~nm}$ in diameter was prepared according to Frens (17) using sodium citrate as a reducing agent. For the localization of cellulosic $\beta$-1,4-glucans, an exoglucanase ( $\beta-1,4-D-$ glucan cellobiohydrolase, EC 3.2.1.21), purified from a cellulase produced by the fungus Trichoderma harzianum, was complexed to colloidal gold at $\mathrm{pH} 9.0$ and used in a one-step procedure (5). Wheat germ agglutinin (WGA), a lectin with $N$-acetylglucosamine binding specificity was used for localizing $N$-acetylglucosamine residues (chitin) according to a previously described procedure (2). Because of its low molecular weight, the lectin could not be directly complexed to colloidal gold. It was used in a two-step procedure, using ovomucoid, conjugated to gold at $\mathrm{pH} 5.4$, as a second step reagent. A $\beta$-1,3-glucanase, purified from tobacco reacting hypersensitively to Tobacco mosaic virus, was used for localizing $\beta$-1,3-glucans (callose) according to a recently described method (3). The enzyme was conjugated to colloidal gold at $\mathrm{pH}$ 5.5. Localization of $\beta$-glucosides (for glycosilated constituents) was performed by using a commercial $\beta$-glucosidase from almond (1). The enzyme was complexed to colloidal gold at $\mathrm{pH}$ 9.3. Localization of lignin-associated phenolic compounds was performed by using a laccase (EC 1.10.3.2) purified from the white rot fungus Rigidoporus lignosus (18). The enzyme was complexed to col- loidal gold at $\mathrm{pH} 4.0$, a $\mathrm{pH}$ value close to its isoelectric point reported to be 3.83 (6). All gold complexes were stored at $4^{\circ} \mathrm{C}$ until use.

Cytochemical labeling. For the direct labeling of cellulosic $\beta$ 1,4-glucans, $\beta$-1,3-glucans, $\beta$-glucosides, and phenolic compounds, ultrathin sections were first incubated on a drop of phosphatebuffered saline (PBS) containing 0.02\% (wt/vol) polyethylene glycol (PEG) 20000 for $5 \mathrm{~min}$ at room temperature. The $\mathrm{pH}$ of the PBS-PEG was adjusted according to the $\mathrm{pH}$ of optimal activity of each protein $(\mathrm{pH} 6.0$ for exoglucanase, $\beta$-1,3-glucanase, and laccase; $\mathrm{pH} 7.0$ for $\beta$-glucosidase). Sections were then transferred to a drop of the gold-complexed probe for $30 \mathrm{~min}$ at room temperature in a moist chamber. After washing with PBS and rinsing with distilled water, grids were stained with uranyl acetate and lead citrate.

For the indirect labeling of $\mathrm{N}$-acetylglucosamine residues, sec-

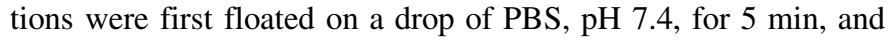
transferred to a drop of WGA $(25 \mu \mathrm{g} / \mathrm{ml}$ in PBS, $\mathrm{pH}$ 7.4) for $60 \mathrm{~min}$ at room temperature in a moist chamber. After washing with PBS, $\mathrm{pH} 7.4$, sections were incubated on a drop of the ovomucoid-gold complex (1:30 in PBS-PEG, $\mathrm{pH}$ 6.0) for $30 \mathrm{~min}$ at room temperature. Sections were washed with PBS, rinsed with distilled water, and contrasted as described previously.

Cytochemical controls. Specificity of labeling was assessed using the following control tests: (i) incubation with the goldcomplexed enzymes to which were previously added the corresponding substrates $(\beta-1,4$-glucans from barley for the exoglucanase, laminarin or laminaribiose for the $\beta$-1,3-glucanase, alicin for the $\beta$-glucosidase, and $p$-coumaric acid, ferulic acid, or sinapinic acid for the laccase, $1 \mathrm{mg} / \mathrm{ml}$ in $\mathrm{PBS}, \mathrm{pH} 7.2$ ); (ii) substitution of the protein-gold complex under study by bovine serum albumin-gold complex to assess nonspecific adsorption of the protein-gold complex to tissue sections; (iii) incubation of tissue sections with protein-gold complexes under nonoptimal conditions for biological activity; (iv) incubation with the WGA with excess $N-N^{\prime}-N^{\prime \prime}$-triacetylchitotriose (1 mg/ml in PBS); and (v) incubation with WGA followed by unlabeled ovomucoid and finally by the ovomucoid-gold complex.

Reagents. The exoglucanase was provided by C. Breuil, Forintek, Canada, and the laccase was obtained from M. Nicole, ORSTOM, Montpellier, France. Tetrachloroauric acid was purchased from

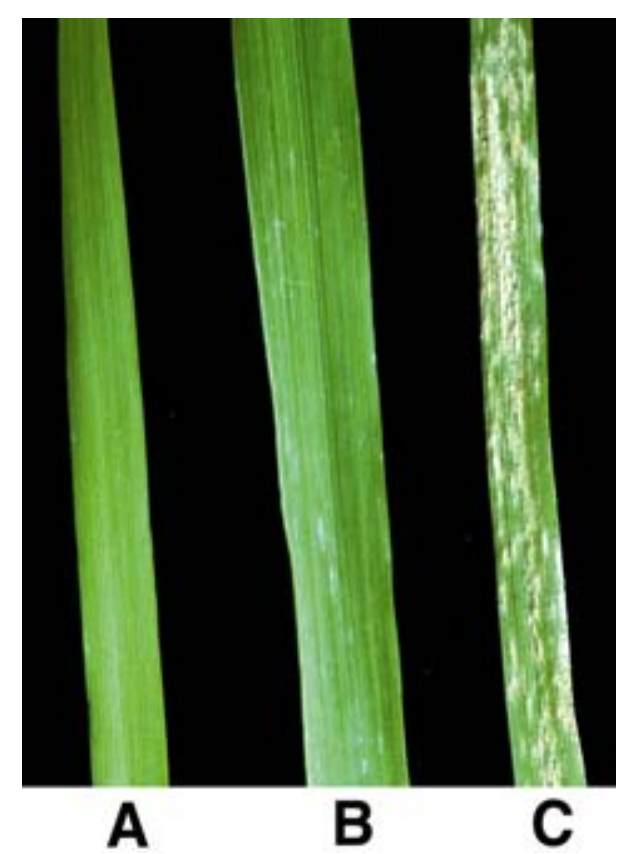

Fig. 1. Effect of silicon amendments (Si+) on powdery mildew (Blumeria graminis f. sp. tritici) incidence on wheat leaves cv. HY 644. A, Noninoculated Si- leaf; $\mathbf{B}$, inoculated $\mathrm{Si}+$ leaf; and $\mathbf{C}$, inoculated $\mathrm{Si}-$ leaf. 
BDH Chemicals, Montreal, Canada. All other reagents for electron microscopy were obtained from JBEM Chemical Co., PointeClaire, Québec, Canada.

\section{RESULTS}

Disease assessment. First signs of $B$. graminis f. sp. tritici colonization were observed on control plants ( $\mathrm{Si}-) 5$ days after inoculation. Disease progressed rapidly thereafter and control plants were heavily infected with powdery mildew colonies after 5 weeks (infection score $=3.71 \pm 0.16$ ). By contrast, $\mathrm{Si}+$ plants and Reclime plants (calcium silicate-Si+) had very few B. graminis f. sp. tritici colonies even after 5 weeks (Fig. 1). At the end of the experimental period, $\mathrm{Si}+$ and Reclime plants had an average infection score of $0.41 \pm 0.06$ and $0.43 \pm 0.12$, respectively, indicating very limited powdery mildew fungal development.
Light microscope observations. Rate and extent of fungal colonization. Light microscopy of $\mathrm{Si}-$ and $\mathrm{Si}+$ wheat leaves showed striking differences in the extent of $B$. graminis f. sp. tritici colonization (Fig. 2). In Si- leaves, B. graminis f. sp. tritici hyphae were abundant on the epidermal surface and freely penetrated the epidermis to form haustoria in $\approx 90 \%$ of the epidermal cells observed (Fig. 2A). By contrast, in $\mathrm{Si}+$ leaves, the degree of fungal colonization was markedly reduced from that in control leaves. Fungal growth in planta was mainly restricted to a few epidermal cells (approximately 10\%) (Fig. 2B). In addition, $B$. graminis f. sp. tritici penetration of the leaf epidermis coincided with cytological changes that were associated with poorly developed haustoria (Fig. 2B, arrows).

Epidermal cell responses. Conidial germination on the epidermal surface led to the formation of appressoria and narrow penetration pegs that penetrated the host cuticle and the underlying

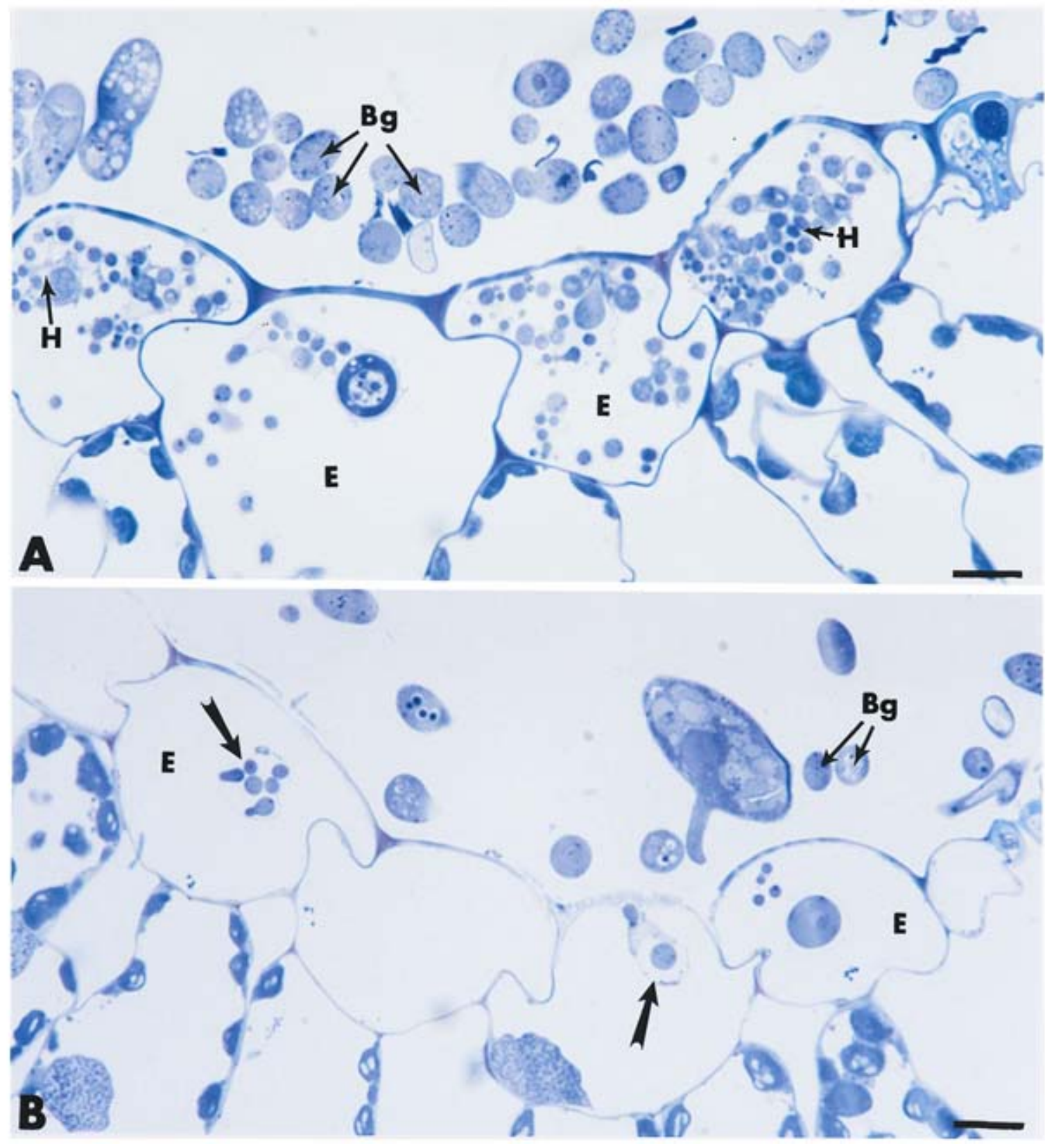

Fig. 2. Light micrographs from wheat leaves infected by Blumeria graminis f. sp. tritici. A, In the absence of silicon (Si-), the fungus has produced abundant hyphae on the cell surface and frequently penetrated the epidermis $(\mathrm{E})$ to form digitate haustoria $(\mathrm{H})$. Bar $=10 \mu \mathrm{m}$. B, Upon treatment with $\mathrm{Si}(\mathrm{Si}+)$, fungal growth in the epidermis (E) was restricted to a few epidermal cells. The haustorial structures are poorly developed (arrows). Bar $=10 \mu \mathrm{m}$. 
epidermal cell walls. Enlargement of the infection pegs in the epidermal cells resulted in the development of multilobed haustoria (Fig. 3A). In transverse sections, haustorial lobes often appeared disconnected from one another (Fig. 3A), whereas in longitudinal sections, the haustoria appeared elongated with typical finger-like lobes (Fig. 3B, arrow). In such heavily infected epidermal cells from $\mathrm{Si}$ - plants, defense reactions including structural barriers and accumulation of newly formed material were rarely seen, with the singular exception of haustorial neck collars (Fig. 3A).

In $\mathrm{Si}+$ leaves, haustoria were abnormally shaped (Fig. 3C, arrow), correlating with a number of epidermal cell reactions that apparently retarded or prevented fungal development and colonization. These reactions involved deposition of a granular material in epidermal cells (Fig. 3C) and papillae in the subtending fungal penetration sites (Fig. 3D). Papillae formed in the reacting epidermal cells were intensely stained with toluidine blue and appeared usually as hemispherical (Fig. 3D).

Light microscopy provided evidence that wheat plants supplied with Si reacted with epidermal cell responses that likely protected their epidermal cells from extensive fungal invasion. A more pre- cise characterization at the ultrastructural level was then deemed essential to understanding how these epidermal cell responses may have resulted in restricting $B$. graminis f. sp. tritici growth and development.

Ultrastructural and cytochemical observations. Si- wheat leaves. Examination of B. graminis f. sp. tritici-infected samples from $\mathrm{Si}$ - wheat leaves by transmission electron microscopy confirmed the extensive $B$. graminis f. sp. tritici colonization seen by light microscopy (Fig. 3A and B). B. graminis f. sp. tritici hyphae grew extensively on the leaf epidermal surface, and penetrated cells had haustoria with elongated necks surrounded by a thick collar composed of layers of differing electron density (Fig. 4A). Haustoria had long, ovoid central bodies with extending fingerlike or digitate lobes. Both the haustorial body and the lobes contained a dense polyribosome-rich cytoplasm in which numerous organelles including mitochondria, vesicles, and dark inclusions could be seen (Fig. 4A to D). In all cases, haustoria were enveloped in a membrane, the extrahaustorial membrane, derived from the host epidermal cell plasma membrane (Fig. 4A and B). Occasionally, a thin layer of host cytoplasm could be visualized

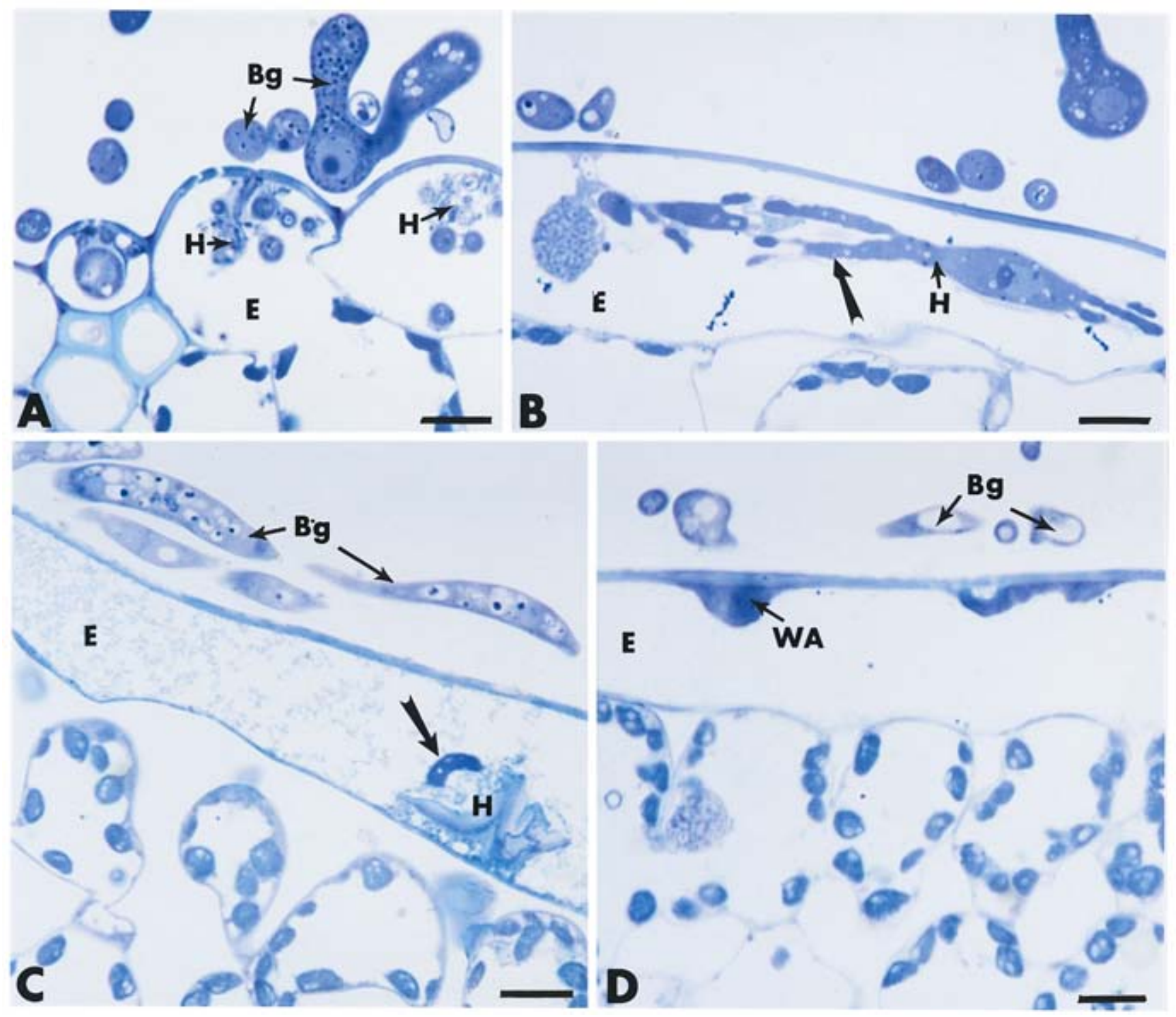

Fig. 3. Light micrographs of samples from wheat leaves infected by Blumeria graminis $\mathrm{f}$. sp. tritici. A and $\mathbf{B}$, In Si- wheat leaves, penetration of $B$. graminis $\mathrm{f}$. sp. tritici $(\mathrm{Bg})$ in the epidermis $(\mathrm{E})$ leads to the formation of haustoria $(\mathrm{H})$ with finger-like lobes $(\mathbf{B}$, arrow). Bars $=10 \mu \mathrm{m}$. $\mathbf{C}$ and $\mathbf{D}$, In $\mathrm{Si}+\mathrm{wheat}$ leaves, haustoria $(\mathrm{H})$ are poorly developed and epidermal cells fill with granular materials $(\mathbf{C}$, arrow). D, Papillae or wall appositions (WA) are formed in the epidermal cells beneath fungal contact and appressorial penetration sites. Bars $=10 \mu \mathrm{m}$. 


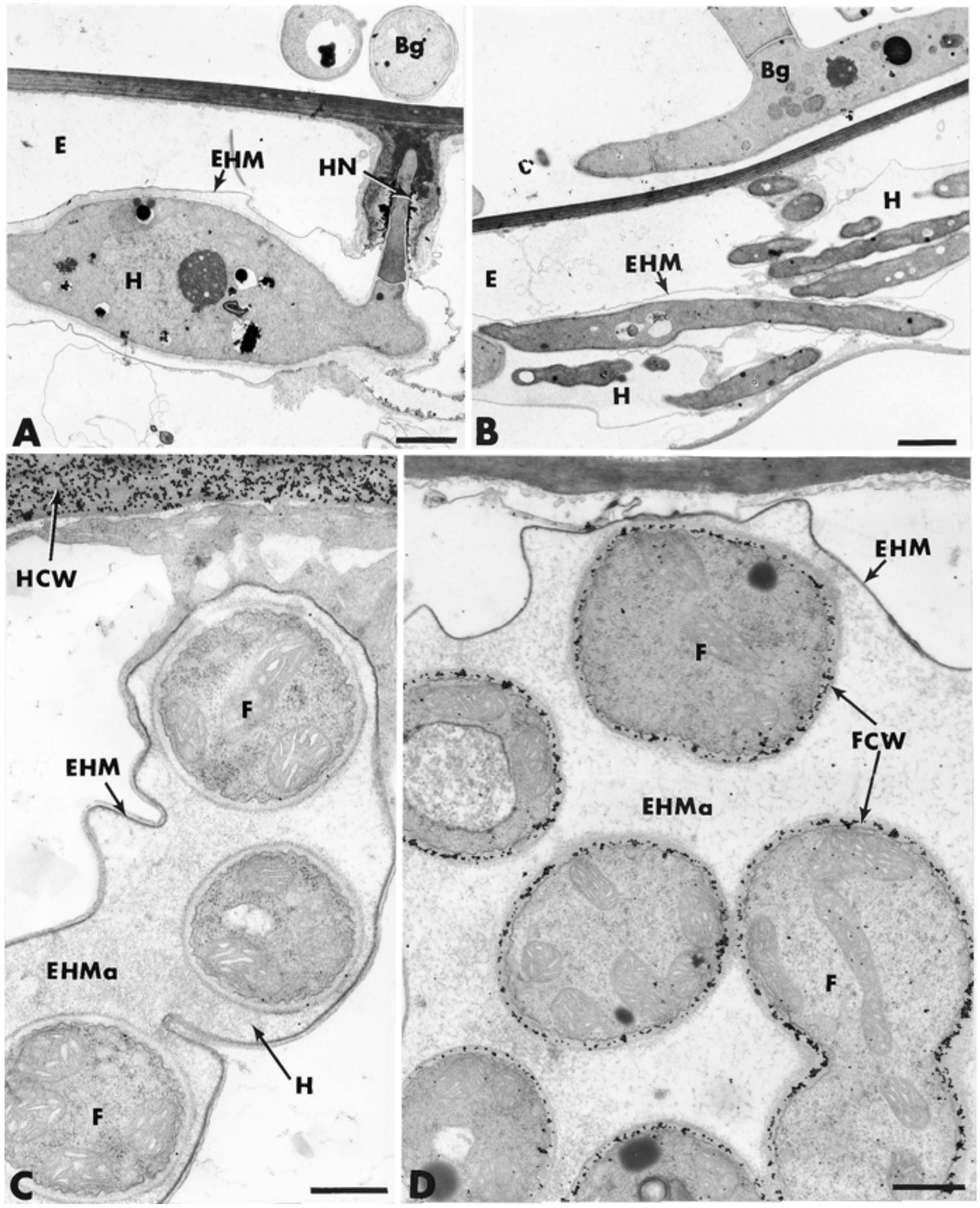

Fig. 4. Transmission electron micrographs of the interaction between Si- wheat leaf tissues and Blumeria graminis f. sp. tritici. A and B, The fungus penetrates the epidermis $(\mathrm{E})$ and the elongated haustorial neck $(\mathrm{HN})$ is surrounded by a thick collar of host cell material origin. The haustorial body $(\mathrm{H})$ is encircled by the extrahaustorial membrane (EHM). Bars $=2 \mu \mathrm{m}$. C, Upon incubation with the $\beta-1,4$ exoglucanase-gold complex for the localization of cellulosic $\beta-1,3$-glucans, the host cell wall $(\mathrm{HCW})$ is intensely labeled whereas the fungal structures including the extrahaustorial membrane (EHM) and the extrahaustorial matrix (EHMa) remain unlabeled. Bar $=0.5 \mu \mathrm{m}$. D, Incubation with the wheat germ agglutinin/ovomucoid-gold complex for the localization of chitin results in a specific labeling of B. graminis f. sp. tritici haustorial cell walls (FCW). The extrahaustorial membrane (EHM) and the extrahaustorial matrix (EHMa) remain unlabeled. $\mathrm{Bar}=0.5 \mu \mathrm{m}$. 
adjacent to the extrahaustorial membrane (Fig. 4C). The extrahaustorial matrix appeared as a network of intermingled fibrils surrounding the polymorphic lobes (Fig. 4C).

Incubation of sections with $\beta-1,4$ exoglucanase-gold complex to reveal cellulose resulted in a heavy deposition of gold particles over the epidermal cell walls; whereas the cytoplasm and fungal structures were unlabeled (Fig. 4C). Upon labeling for chitin with the WGA/ovomucoid-gold complex, gold particles were uniformly distributed over the fungal cell walls. By contrast, the extrahaustorial membrane and the extrahaustorial matrix were free of labeling (Fig. 4D).

Si+ wheat leaves. As with light microscopy, penetration attempts in $\mathrm{Si}+$ leaves were often associated with the deposition of wall papillae (Fig. 5A and B). The papillae usually consisted of an amorphous matrix impregnated by osmiophilic substances and were seldom penetrated by the fungus (Fig. 5A). However, in other cases in which the fungus successfully entered the host epidermal cell wall, an osmiophilic electron-opaque material, reacting positively for the presence of $\beta$-1,3-glucans (callose constituents), was found to entirely coat the embryonic haustorial structure (Fig. $5 B$ ). Interestingly, a number of vesicles containing $\beta$-1,3-glucans (callose) were always seen in the vicinity of the coating material (Fig. 5B, arrows). Both the impregnated papillae and the newly formed material encasing haustoria were apparently effective in reducing fungal ingress because well-developed normal haustoria were seldom found.

Another epidermal cell reaction in $\mathrm{Si}+$ plants was the deposition of an osmiophilic electron-dense material lining epidermal cell walls near sites of potential fungal penetration (Fig. 5C and D). This material, which reacted positively with the gold-complexed laccase for the presence of phenolic compounds, usually extended inward to form polymorphic deposits that were nearly unlabeled (Fig. 5D). When epidermal cells were colonized by $B$. graminis f. sp. tritici, similar electron-dense deposits were detected (Fig. 6A and B). Observations at high magnification revealed that the deposits accumulated not only in the cell lumen but also in the epidermal cell walls (Fig. 6B, arrow), and along the extrahaustorial membrane (Fig. 6B, double arrows), forming, at an advanced stage of the interaction, a nearly uniform coating (Fig. 6C). A close examination of a large number of leaf sections revealed that the electron-dense material not only surrounded the extrahaustorial membrane but also appeared to infiltrate the extrahaustorial matrix to form a dense layer over the fibrillar network (Fig. 6C). Haustoria, encased in this osmiophilic material, had various anomalies ranging from increased vacuolation (Fig. 6C) to complete disorganization (Fig. 7A). Upon incubation with the WGA/ovomucoid-gold complex for the presence of chitin, a regular deposition of gold particles occurred on the walls of haustoria surrounded by the osmiophilic phenolic material (Fig. 6D).

At an advanced stage of colonization, large deposits, apparently resulting from the fusion of electron-dense droplets containing phenolics, established intimate contact with haustoria (Fig. 7A). Haustoria, encased in impregnated extrahaustorial membranes, were highly altered and, in most cases, it was difficult to clearly identify them (Fig. 7A, arrows). In the vicinity of such highly disorganized haustoria, a large number of extrahaustorial membrane remnants were the only indication of previously living haustoria (Fig. 7A, double arrows).

Upon incubation with gold-complexed $\beta$-glucosidase to identify glycosilated materials, labeling was found to be predominantly associated with the electron-dense aggregates occurring in the lumen of reacting $\mathrm{Si}+$ epidermal cells and to a lesser extent in cojunction with extrahaustorial membranes (Fig. 7B). Gold particles could also be seen in the fungal cytoplasm. Labeling for phenolic compounds with the laccase-gold complex resulted in deposition of gold particles over the electron-dense aggregates, whereas all other structures were very slightly labeled (Fig. 7C).

\section{DISCUSSION}

Results from this study provide strong evidence that silicon amendments mediate an effective protection against wheat powdery mildew fungal infection and colonization. This report confirms numerous observations on the beneficial role of $\mathrm{Si}$ in monocots (14). However, few previous studies have focused directly on the wheat-powdery mildew pathosystem with the exception of Leusch and Buchenauer (30). Of additional interest is the fact that disease protection on wheat plants occurred whether silicon was supplied in a nutrient solution or in the form of calcium silicate slag (Reclime).

The practice of amending soils with calcium silicate slag has other positive effects for many plant species including higher yields and disease resistance in several crops (11). Several recent reviews have discussed the possible physiological role of $\mathrm{Si}$, but these remain controversial and poorly understood $(13,14,23)$. In this study, microscopical analyses of the wheat $-B$. graminis $\mathrm{f}$. sp. tritici interaction have described cytological phenomena associated with reduced infection levels correlated with $\mathrm{Si}$ amendments.

The first difference noted between $\mathrm{Si}-$ and $\mathrm{Si}+$ plants inoculated with $B$. graminis f. sp. tritici was the extent of fungal colonization. This observation is noteworthy because it demonstrates that although B. graminis f. sp. tritici is capable of infecting epidermal cells of $\mathrm{Si}+$ plants, its rate of development was altered. To date, epidermal cells of cereals were understood to have two active defense mechanisms against $B$. graminis f. sp. tritici attack: (i) penetration resistance associated with papilla formation; and (ii) hypersensitive epidermal cell death (HR) $(38,43)$. Our observations indicate that there is yet a third line of active defense characterized by a marked accumulation of phenolic compounds in infected $\mathrm{Si}+$ epidermal cells.

Considering the first active defense reaction, papilla formation, our observations confirm the association of papillae with penetration resistance by wheat cells against $B$. graminis $\mathrm{f}$. sp. tritici. As discussed by Zeyen et al. (43), papillae relate to powdery mildew fungal penetration in two distinct ways: (i) failed penetration; and (ii) successful penetration where papillae become haustorial neck collars. Both outcomes were observed in this work, in both $\mathrm{Si}+$ and $\mathrm{Si}-$ plants, confirming that deposition of papilla formation may not be sufficient by itself to explain the level of protection observed with $\mathrm{Si}+$ treatment. However, the prevalence of papillae in $\mathrm{Si}+$ treatment compared with $\mathrm{Si}$ - treatment does suggest that $\mathrm{Si}$ has somehow stimulated their formation.

In $\mathrm{Si}+$ wheat epidermal cells, papillae were observed to form on the inner surface of epidermal cell walls and were successful in preventing penetration by only a proportion of penetration pegs. Kunoh and Ishizaki (26-28), Kunoh et al. (29), and Carver et al. (7) found that $\mathrm{Si}$ deposition occurred in barley epidermal cells beneath sites of attempted penetration by B. graminis f. sp. hordei and that $\mathrm{Si}$ accumulated in the halo, papilla, and haustorial neck and collar areas irrespective of the outcome of the attempted penetration. Samuels et al. $(35,36)$ reported similar results with the powdery mildew-cucumber pathosystem, suggesting that insoluble $\mathrm{Si}$ deposition is a common phenomenon in both dicots and monocots. In a different pathosystem, Chérif et al. (10) concluded that the increased resistance of cucumber to Pythium ultimum, induced by exogenously supplied $\mathrm{Si}$, was not associated with insoluble $\mathrm{Si}$ accumulation at sites of pathogen penetration, regardless of the plant organ studied. They concluded that accumulation and polymerization of insoluble $\mathrm{Si}$ at fungal penetration sites or in epidermal cell walls did not appear to be a physical barrier against fungal attack. A similar conclusion was raised by Kunoh and Ishizaki (26) and Carver et al. (7).

The encasement of haustoria by callose (Fig. 5B) suggests that the polysaccharide can play an important role in preventing haustorium formation. Accumulation of callose in papillae has been previously linked to high $\mathrm{Si}$ content in epidermal cells (43). How- 


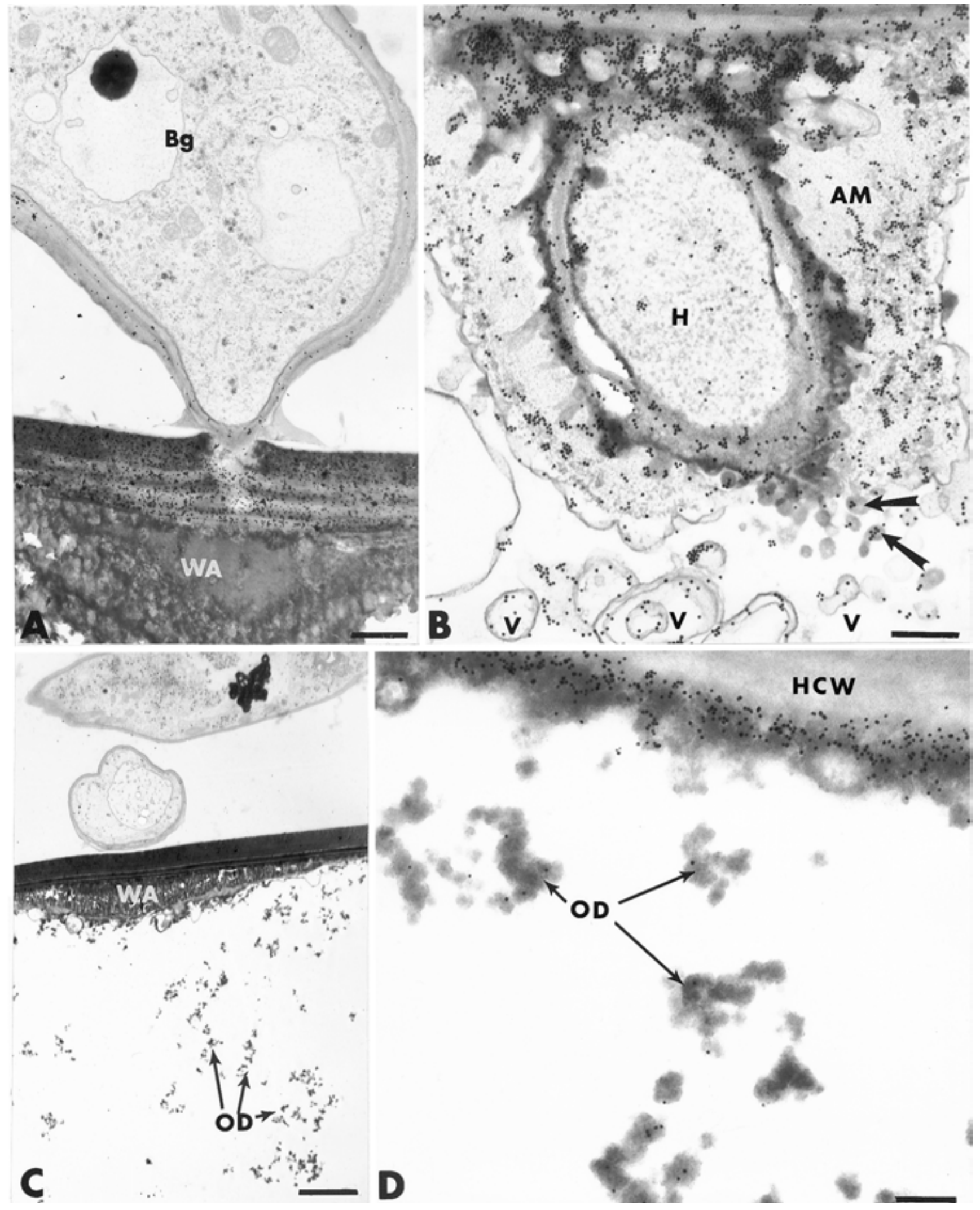

Fig. 5. Transmission electron micrographs of the interaction between Si+ wheat leaf tissues and Blumeria graminis f. sp. tritici (Bg). A, An unsuccessful attempt of the pathogen to penetrate a papilla or wall apposition (WA) is observed. Bar $=0.5 \mu \mathrm{m}$. $\mathbf{B}$, Amorphous material (AM), reacting positively with the $\beta$ 1,3-glucanase-gold complex for the localization of callose, envelops the haustorial structure $(\mathrm{H})$. A number of labeled vesicles $(\mathrm{V})$ are seen in the vicinity of the coating material (arrows). Bar $=0.25 \mu \mathrm{m}$. C and D, Besides the formation of wall appositions (WA), osmiophilic deposits (OD) fill the epidermal cells and accumulate in the host cell lumen and in the apoplastic space. D, The material lining the host cell wall (HCW) reacts positively with the gold-complexed laccase for the localization of phenolics, whereas the polymorphic deposits in the cell lumen are mostly unlabeled. $\mathbf{C}, \mathrm{Bar}=2 \mu \mathrm{m} ; \mathbf{D}, \mathrm{Bar}=0.25 \mu \mathrm{m}$. 
ever, while callose is invariably found in papillae, Smart et al. (37) presented evidence that callose was not an effective barrier to penetration by $B$. graminis f. sp. tritici in barley epidermal cells. Zeyen et al. (41) suggested that callose in barley and oat epider- mal cells was simply a matrix for other constituents. Whether or not callose plays a different role in wheat epidermal cells is unknown but our results support a direct role for callose in altering B. graminis f. sp. tritici haustorium development in $\mathrm{Si}+$ plants.

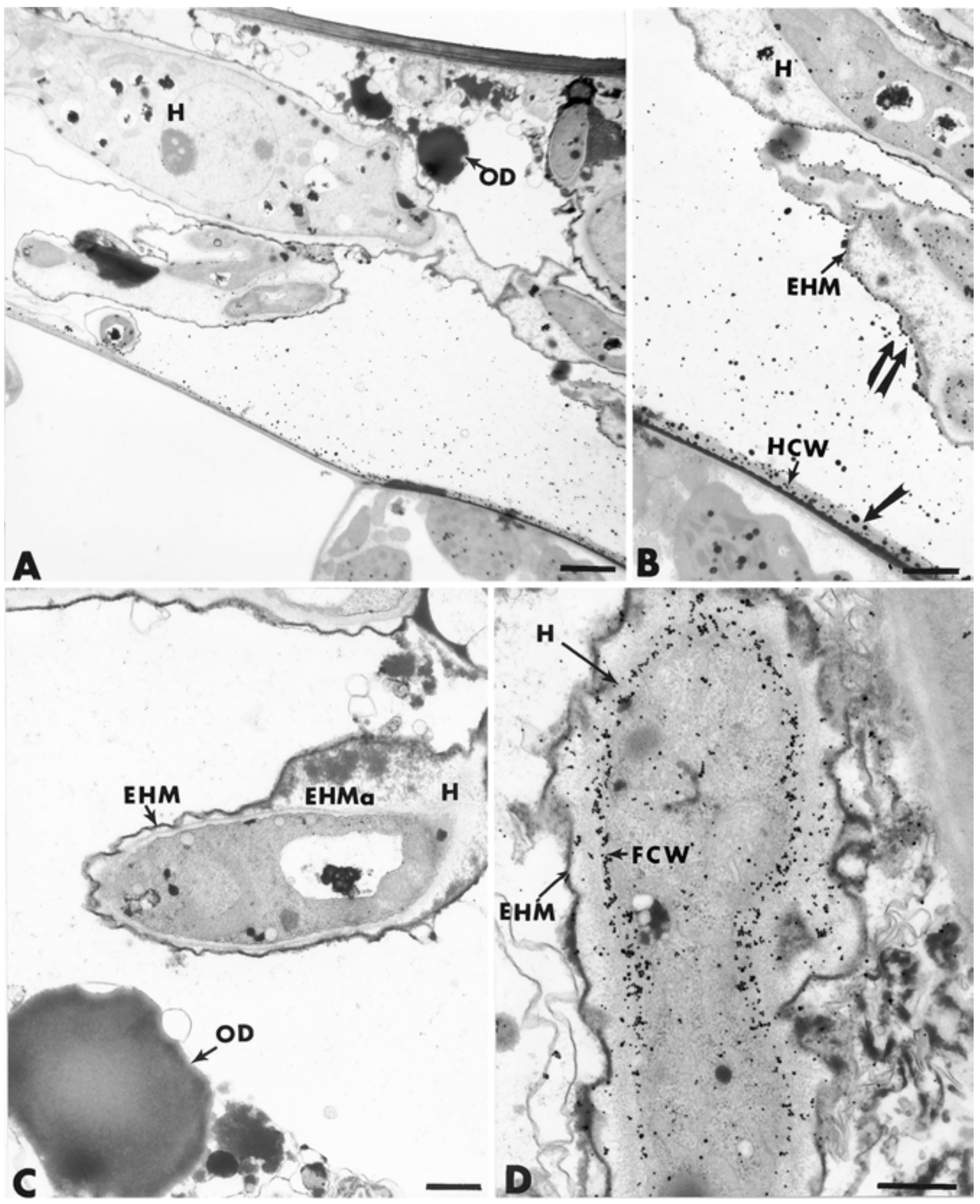

Fig. 6. Transmission electron micrographs of the interaction between $\mathrm{Si}+$ wheat leaf tissues and Blumeria graminis $\mathrm{f}$. sp. tritici. A, A large number of osmiophilic deposits (OD) occur in epidermal cells colonized by the fungus. B, These deposits accumulate in epidermal cell walls (HCW, arrow) and along the extrahaustorial membrane (EHM, double arrows). A, Bar $=2 \mu \mathrm{m} ; \mathbf{B}$, Bar $=1 \mu \mathrm{m}$. C, The osmiophilic material apparently infiltrates the extrahaustorial matrix (EHMa) to form a dense layer over the fibrillar network. D, An extrahaustorial membrane (EHM) is entirely coated by osmiophilic deposits (OD). D, Upon incubation with the chitin-specific wheat germ agglutinin/ovomucoid-gold complex, a regular deposition of gold particles occurs over the fungal cell walls (FCW). C and D, Bars $=0.5 \mu \mathrm{m}$. 


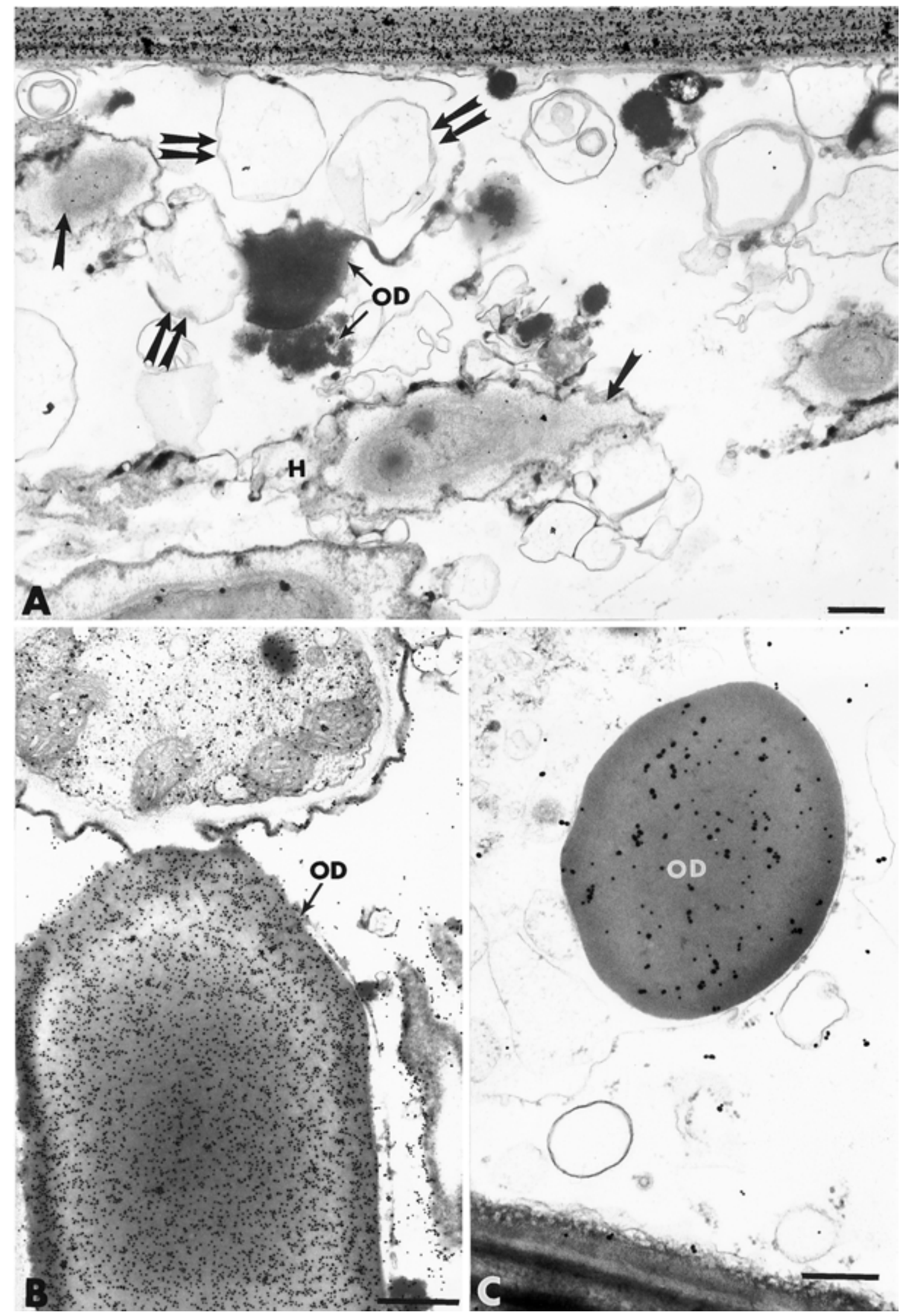

Fig. 7. Transmission electron micrographs of the interaction between $\mathrm{Si}+$ wheat leaf tissues and Blumeria graminis f. sp. tritici. A, The osmiophic deposits (OD) are in close contact with altered haustorial bodies ( $\mathrm{H}$, single arrows). In the vicinity of such highly disorganized haustorial bodies, a number of extrahaustorial membrane remnants are the only indication of previously living fungal entities (double arrows). Bar $=0.5 \mu \mathrm{m}$. B and $\mathbf{C}$, The osmiophilic deposits (OD) occurring in the lumen of reacting epidermal cells and, to a lesser extent, associated with the extrahaustorial membranes contain glycosides and are intensely labeled with the gold-complexed $\beta$-glucosidase. $\mathbf{C}$, Such deposits have apparent phenolic constituents because they are slightly labeled with the laccase-gold complex. Bars $=0.5 \mu \mathrm{m}$. 
In previous ultrastructural studies of other cereal powdery mildews, HR was reported as a common phenomenon in incompatible interactions (20). Although in this work some epidermal cells showed degrees of degeneration, suggesting cell death (Fig. 3C), the possibility that HR occurred as a main line of defense remains difficult to establish on the basis of our observations. Rather, the degradation of fungal structures within epidermal cells of $\mathrm{Si}+$ plants revealed specific active defense responses.

The greatest cytochemical difference between $\mathrm{Si}-$ and $\mathrm{Si}+$ plants was the extensive deposition of phenolic compounds in the infected epidermal cells of $\mathrm{Si}+$ plants. These phenolic compounds accumulated along the epidermal cell wall and on the extrahaustorial membrane. Silicon, in the form of $\mathrm{Si}(\mathrm{OH})_{4}$, possesses strong affinities for organic polyhydroxyl compounds which participate in the synthesis of lignin $(21,22)$. This affinity of Si may explain its tendency to accumulate in mature cell walls of plants or during a pathogen attack. Maturity and pathogen attack correspond with a radical change in the constitution of the cell wall, with the infusion of lignin $(21,22,24,31,34)$. Once polymerized, Si participates in the rigidification of cell walls with lignin, a process that is confined to the periphery of the plant where evapotranspiration occurs.

In the Erysiphe graminis f. sp. hordei-barley pathosystem, Koga et al. (25) hypothesized that during HR, phenolics were released and accumulated on cell walls and if soluble $\mathrm{Si}$ was present, it would form insoluble complexes with the phenolics. In such cases, it was suggested that insoluble Si was secondary to HR and played a passive role. However, in the current study, given that the host cells were already infected and that the phenolics appeared to have a direct and toxic effect on haustoria, it is unlikely that $\mathrm{Si}$ is simply playing a passive role by combining with phenolics to make epidermal cell walls more rigid against pathogen penetration. Rather, the fact that phenolic compounds were localized in close association with degraded haustoria (Fig. 7) suggests a complex interaction between soluble $\mathrm{Si}$ and production of metabolites involved in the protection of the cell.

To our knowledge, this is the first report linking Si amendments with cytological events elicited in cell defense reactions of monocots. Previous studies with dicots, namely cucumber, suggested involvement of phenolics in Si-mediated resistance $(9,32)$. In addition, Chérif et al. (8) was able to show a marked increase in the concentration of antifungal phenolic materials in P. ultimuminfected $\mathrm{Si}+$ cucumber tissues. Further biochemical analyses identified some of these metabolites as flavonoids and phenolic acids that accumulated specifically and strongly in a manner typical of phytoalexins (15). The fungitoxicity of these phenolic compounds was more apparent after acid hydrolysis. Therefore, Benhamou and Bélanger (4) suggested that the release of aglycones in the plant could be regulated in part by the pathogen itself. They showed that only the conjugated phenolics in close proximity to fungal structures were converted to their active state, presumably by Pythium or Pythium-induced plant enzymes. Interestingly, a similar phenomenon may be happening in the epidermal cells of Si+ wheat infected with $B$. graminis f. sp. tritici. The phenolic materials associated with and near the epidermal cell walls were strongly labeled with the gold-complexed $\beta$-glucosidase (Fig. 7b), indicating that they were in a glycosylated form; conversely, phenolic material in the cell near the extrahaustorial membrane showed much less labeling for glycosilated phenolics, suggesting that these phenolics were not heavily glycosylated and were likely in a fungitoxic form.

In conclusion, this work provides evidence that $\mathrm{Si}$ amendments to wheat plants mediate $B$. graminis f. sp. tritici resistance in more complex ways than originally thought. More specifically, the production of phenolic materials in powdery mildew-infected leaves of $\mathrm{Si}+$ wheat plants suggests an active role for $\mathrm{Si}$ in mediating powdery mildew resistance. These results also suggest that the protective role of Si may be similar in both monocots (or at least wheat) and dicots. While the exact mode of action of Si in influencing plant resistance is not fully understood, Fawe et al. (16) suggested that $\mathrm{Si}$ may mediate defense responses that are functionally similar to systemic acquired resistance. In $\mathrm{Si}+$ plants, the amplitude of expression of defense responses appears greatly increased.

\section{ACKNOWLEDGMENTS}

This study was funded by RECMIX Inc., the Natural Sciences and Engineering Research Council University-Industry Program, and the Canada Research Chairs Program to R. R. Bélanger. We thank A. Vivien and A. Goulet for technical assistance.

\section{LITERATURE CITED}

1. Bendayan, M., and Benhamou, N. 1987. Ultrastructural localization of glucoside residues on tissue sections by applying the enzyme-gold approach. J. Histochem. Cytochem. 35:1149-1156.

2. Benhamou, N. 1989. Preparation and application of lectin-gold complexes. Pages 205-218 in: Colloidal Gold, Principles, Methods and Applications, Vol. I. J. R. Latgé and D. Boucias, eds. Springer-Verlag, Berlin.

3. Benhamou, N. 1992. Ultrastructural and cytochemical aspects of chitosan on Fusarium oxysporum f. sp. radicis-lycopersici, agent of tomato crown and root rot. Phytopathology 82:1185-1193.

4. Benhamou, N., and Bélanger, R. R. 1998. Induction of systemic resistance to Pythium damping-off in cucumber plants by benzothiadiazole: Ultrastructure and cytochemistry of the host response. Plant J. 14:13-21.

5. Benhamou, N., Chamberland, H., Ouellette, G. B., and Pauzé, F. J. 1987. Ultrastructural localization of $\beta$-(1-4)-D-glucans in two pathogenic fungi and in their host tissues by means of an exoglucanase-gold complex. Can. J. Microbiol. 33:405-417.

6. Benhamou, N., Lafontaine, P. J., and Nicole, M. 1994. Seed treatment with chitosan induces systemic resistance to Fusarium crown and root rot in tomato plants. Phytopathology 84:1432-1444.

7. Carver, T. L. W., Zeyen, R. J., and Ahlstrand, G. G. 1987. The relationship between insoluble silicon and success or failure of attempted primary penetration by powdery mildew (Erysiphe graminis) germlings on barley. Physiol. Mol. Plant Pathol. 31:133-148.

8. Chérif, M., Asselin, A., and Bélanger, R. R. 1994. Defense responses induced by soluble silicon in cucumber roots infected by Pythium spp. Phytopathology 84:236-242.

9. Chérif, M., Benhamou, N., Menzies, J. G., and Bélanger, R. R. 1992. Silicon induced resistance in cucumber plants against Pythium ultimum. Physiol. Mol. Plant Pathol. 41:411-425.

10. Chérif, M., Menzies, J. G., Benhamou, N., and Bélanger, R. R. 1992. Studies of silicon distribution in wounded and Pythium ultimum infected cucumber plants. Physiol. Mol. Plant Pathol. 41:371-385.

11. Datnoff, L. E., Snyder, G. H., and Korndörfer, G. H. 2001. Silicon in Agriculture. Elsevier Science B.V., Amsterdam.

12. Deren, C. W. 2001. Plant genotype, silicon concentration, and siliconrelated responses. Pages 149-158 in: Silicon in Agriculture. L. E. Datnoff, G. H. Snyder, and G. H. Korndörfer, eds. Elsevier Science B.V., Amsterdam.

13. Epstein, E. 1994. The anomaly of silicon in plant biology. Proc. Nat. Acad. Sci. USA 91:11-17.

14. Epstein, E. 2001. Silicon in plants: Facts vs. concepts. Pages 1-15 in: Silicon in Agriculture. L. E. Datnoff, G. H. Snyder, and G. H. Korndörfer, eds. Elsevier Science B.V., Amsterdam.

15. Fawe, A., Abou-Zaid, M., Menzies, J. G., and Bélanger, R. R. 1998. Silicon-mediated accumulation of flavonoid phytoalexins in cucumber. Phytopathology 88:396-401.

16. Fawe, A., Menzies, J. G., Chérif, M., and Bélanger, R. R. 2001. Silicon and disease resistance in dicotyledons. Pages 159-169 in: Silicon in Agriculture. L. E. Datnoff, G. H. Snyder, and G. H. Korndörfer, eds. Elsevier Science B.V., Amsterdam.

17. Frens, G. 1973. Controlled nucleation for regulation of the particle size in monodisperse gold suspensions. Nature (Lond.) Phys. Sci. 241:20-22.

18. Geiger, J.-P., Nicole, M., Nandris, D., and Rio, B. 1986. Root rot diseases of Hevea brasiliensis. I. Physiological and biochemical aspects of host aggression. Eur. J. For. Pathol. 16:22-37.

19. Germar, B. 1935. Über einige Wirkungen der Kieselsäure in Getreidepflanzen, insbesondere auf deren resistenz gegenüber mehittau (on some effects of silicic acid on cereal plants, especially on their resistance to mildew). Rev. Appl. Mycol. 14:25-26.

20. Hippe-Sanwald, S., Hermanns, M., and Somerville, S. C. 1992. Ultrastructural comparison of incompatible and compatible interactions in the 
barley powdery mildew disease. Protoplasma 168:27-40.

21. Inanaga, S., and Okasaka, A. 1995. Calcium and silicon binding compounds in cell walls of rice shoots. Jpn. J. Soil Sci. Plant Nutr. 41:103110.

22. Inanaga, S., Okasaka, A., and Tanaka, S. 1995. Does silicon exist in association with organic compounds in rice plant? Jpn. J. Soil Sci. Plant Nutr. 41:111-117.

23. Ishiguro, K. 2001. Review of research in Japan on the roles of silicon in conferring resistance against rice blast. Pages 277-291 in: Silicon in Agriculture. L. E. Datnoff, G. H. Snyder, and G. H. Korndörfer, eds. Elsevier Science B.V., Amsterdam.

24. Jones, L. H. P., and Handreck, K. A. 1967. Silica in soils, plants and animals. Adv. Agron. 19:107-149.

25. Koga, H., Zeyen, R. J., Bushnell, W. R., and Ahlstrand, G. G. 1988. Hypersensitive cell death, autofluorescence, and insoluble silicon accumulation in barley leaf epidermis cells under attack by Erysiphe graminis $\mathrm{f}$. sp. hordei. Physiol. Mol. Plant Pathol. 32:395-409.

26. Kunoh, H., and Ishizaki, H. 1975. Silicon levels near penetration sites of fungi on wheat, barley, cucumber and morning glory leaves. Physiol. Plant Pathol. 5:283-287.

27. Kunoh, H., and Ishizaki, H. 1976. Accumulation of chemical elements around the penetration sites of Erysiphe graminis hordei on barley leaf epidermis. II. Level of silicon in papilla around the haustorial neck. Ann. Phytopathol. Soc. Jpn. 42:30-34.

28. Kunoh, H., and Ishizaki, H. 1976. Accumulation of chemical elements around the penetration sites of Erysiphe graminis hordei on barley leaf epidermis. III. Micromanipulation and X-ray microanalysis of silicon. Physiol. Plant Pathol. 8:91-96.

29. Kunoh, H., Ishizaki, H., and Kondo, F. 1975. Composition analysis of 'halo' area of barley leaf epidermis induced by powdery mildew infection. Ann. Phytopathol. Soc. Jpn. 41:33-39.

30. Leusch, H.-J., and Buchenauer, H. 1989. Effects of soil treatments with silica-rich fertilizers and sodium trisilicate on the incidence of Erysiphe graminis and Septoria nodorum depending on the form of $\mathrm{N}$ fertilizer. Z. Pflanzenkr. Pflanzensh. 96:154-172.

31. Marschner, H. 1986. Beneficial mineral elements. Silicon. Pages 351359 in: Mineral Nutrition of Higher Plants. H. Marschner, ed. Academic Press, London.

32. Menzies, J. G., Ehret, D. L., Glass, A. D. M., and Samuels, A. L. 1991.
The influence of silicon on cytological interactions between Sphaerotheca fuliginea and Cucumis sativus. Physiol. Mol. Plant Pathol. 39:403414.

33. Miyake, Y., and Takahashi, E. 1983. Effect of silicon on the growth of solution-cultured cucumber plants. Jpn. J. Soil Sci. Plant Nutr. 29:71-83.

34. Perry, C. C., Williams, R. J. P., and Fry, S. C. 1987. Cell wall biosynthesis during silicification of grass hairs. J. Plant Physiol. 126:437-448.

35. Samuels, A. L., Glass, A. D. M., Ehret, D. L., and Menzies, J. G. 1991. Distribution of silicon in cucumber leaves during infection by powdery mildew fungus (Sphaerotheca fuliginea). Can. J. Bot. 69:140-146.

36. Samuels, A. L., Glass, A. D. M., Menzies, J. G., and Ehret, D. L. 1994. Silicon in cell walls and papillae of Cucumis sativus during infection by Sphaerotheca fuliginea. Physiol. Mol. Plant Pathol. 44:237-242.

37. Smart, M. G., Aist, R. J., and Israel, H. W. 1986. Structure and function of wall appositions. 2. Callose and the resistance of oversize papillae to penetration by Erysiphe graminis f. sp. hordei. Can. J. Bot. 64:802-804.

38. Thordal-Christensen, H., Gregersen, P. L., and Collinge, D. 2000. The barley/Blumeria (syn. Erysiphe) graminis interaction. Pages 77-100 in: Mechanisms of Resistance to Plant Disease. A. Slusarenko, R. S. S. Fraser, and L. C. van Loon, eds. Kluwer Academic Publishers, London.

39. Wagner, F. 1940. Die Bedeutung der Kieselsäure für das Wachstum einiger Kulturpflanzen, ihren Nährstoffhaushalt und ihre Anfälligkeit gegen echte Mehltaupilze. Phytopathol. Z. 12:427-479.

40. Yoshida, S., Ohnishi, Y., and Kitagishi, K. 1962. Histochemistry of silicon in rice plant. III. The presence of cuticle-silica double layer in the epidermal tissue. Jpn. J. Soil Sci. Plant Nutr. 8:107-113.

41. Zeyen, R. J., Ahlstrand, G. G., and Carver, T. L. W. 1993. X-ray microanalysis of frozen-hydrated, freeze-dried, and critical point dried leaf specimens: Determination of soluble and insoluble chemical elements at Erysiphe graminis epidermal cell papilla sites in barley isolines containing $M l-o$ and $m l-o$ alleles. Can. J. Bot. 71:284-296.

42. Zeyen, R. J., Carver, T. L. W., and Ahlstrand, G. G. 1983. Relating cytoplasmic detail of powdery mildew infection to presence of insoluble silicon by sequential use of light microscopy, SEM and X-ray microanalysis. Physiol. Plant Pathol. 22:101-108.

43. Zeyen, R. J., Carver, T. L. W., and Lyngkjaer, M. F. 2002. The formation and role of papillae. Pages 107-125 in: The Powdery Mildews: A Comprehensive Treatise. R. R. Bélanger, W. R. Bushnell, A. J. Dik, and T. L. W. Carver, eds. The American Phytopathological Society, St. Paul, MN. 